\title{
Sufficiency of Investments in Environmental Policy of Mining Region
}

\author{
Ludmila Starikova ${ }^{1, *}$, and Irina Trapeznikova ${ }^{2}$ \\ ${ }^{1}$ Russian Economic University named after G.V. Plekhanov, Kemerovo Institute, 650025 Kuznetskiy \\ pr-t 39, Kemerovo, Russia \\ ${ }^{2}$ Kemerovo State University, 650000 Krasnaya str 6, Kemerovo, Russia
}

\begin{abstract}
Since 2005, expenditures on research, development and technological work (R \& D) have been allocated in the structure of investments in non-financial assets. The absence of methodological developments on a comprehensive analysis of indicators of environmental and economic efficiency does not allow us to clearly determine the real costs of creating a system of rational nature use and environmental protection. In order to, at least approximately estimate the necessary level of investment in the restoration of the environment, it is necessary to conduct a study of the relationship between investment and environmental activities through the interrelationship between the concepts of "investment" and "capital investments".
\end{abstract}

\section{Introduction}

According to the Federal State Statistics Service, the largest share in the structure of investments in non-financial assets is occupied by investments in fixed assets - more than $98 \%$ [1]. As a result of investments of this type, the capital of the future enterprise is formed, the existing capital is increased. The use of the term "capital investment" is associated with this.

Investments in fixed assets are carried out in the form of capital investments and have one more definition - real investments. It should be noted that the term "investment" has become widely used in domestic practice with the transition to a market economy and the development of forms of ownership. In the period of the administrative-planned economy, the concept of "capital investments" was used. In accordance with the formulation of the law, "capital investments are investments in fixed assets (fixed assets), including the costs of new construction, expansion, reconstruction and technical re-equipment of existing enterprises, the acquisition of machinery, equipment, tools, project-but-exploration works and other costs," [2, 3] and the process of implementing capital-forming investments is called an investment process.

The limited economy of resources and investments makes it necessary to choose certain priorities in environmental and economic policy. The most common now is the demand for a sharp increase in the costs of conservation. In this case, the share of such funds in the total amount of investments in the economy, the gross national product, comparison of these

* Corresponding author: $\underline{\sin 55 @ \text { list.ru }}$ 
indicators with developed countries, etc., are often compared. But at the same time under the costs of nature protection means only costs in direct environmental protection measures (sewage treatment plants, filters of various kinds, reclamation, etc.). However, this is an incorrect approach. There is an experience of developed countries, where for a long time they constantly increased investments in direct environmental protection measures, however, as such costs increased, their low efficiency began to be revealed. Weak, compared with other spheres of management, susceptibility to the achievements of scientific and technological progress. Insufficiency of "power" methods of nature protection and the need for their reinforcement by a powerful system of economic regulation. It is necessary to make investments where they will give the maximum ecological and economic effect, will be most effective.

The issue of the formation of an adequately necessary level of investment in fixed assets aimed at protecting the environment and rational use of the environment is closely linked to the issue of the formation and implementation of a system of economic instruments in environmental policy, since it is the use of such systems that creates additional important sources of income for financing of investment programs, reduce activities leading to pollution through investment in environmental projects, to improve integration of environmental policy with economic policy.

The theory of the question of the magnitude of environmental costs is the same in all cases, the specific amount of investment is determined depending on the actual situation.

\section{Materials and methods}

In this work, we tried to calculate the necessary volume of investment in fixed assets aimed at protecting the natural environment for Kemerovo region.

While writing this work, we proceeded from the assumption that the entry of polluting substances into the natural environment is a consequence of the activities of certain industries under certain production methods. It was assumed that the volumes of contaminants are directly related to the volumes of industrial production.

Taking into account that in the economy of nature management one of the main environmental and economic laws relates to the relationship between the amount spent for environmental protection and the state of the environment, we assume that the amount of investment directed to the restoration of the quality of nature should also depend on volume of production.

For the given will be accepted the fact that the operation of industrial resource-intensive production is impossible without environmental pollution, and in this case the model of investment level formation aimed at rational nature management and necessary for environmental restoration will look like this.

In the case that the nature protection measures are completely absent, the volume of industrial production is proportional to the pollution of atmospheric air and water objects.

In reality, it is impossible to operate the industry without the costs of protecting the environment. These costs, obviously, reduce the volume of industrial production.

Values to estimate the state of the environment are given in Table 1.

Based on these statistics, a regression model has been obtained that describes the dependence of the volume of industrial production on investment, the amount of emissions into the atmosphere, and discharges into surface water bodies.

The quality of the model is estimated in Table 2. 
Table 1. Statistical data on the state of the environment for the period 1995-2001.

\begin{tabular}{|c|c|c|c|c|}
\hline Years & $\begin{array}{l}\text { The volume of invest- } \\
\text { ment in the fixed capital } \\
\text { to protect the surround- } \\
\text { ing natural environment }\end{array}$ & $\begin{array}{l}\text { Emissions to } \\
\text { the } \\
\text { phere, thou- } \\
\text { and tons }\end{array}$ & $\begin{array}{l}\text { The volume } \\
\text { of polluted } \\
\text { sewage, } \\
\text { thous. tons }\end{array}$ & $\begin{array}{l}\text { The volume } \\
\text { of industrial } \\
\text { production, } \\
\text { billion rubles }\end{array}$ \\
\hline 1997 & 0.97 & 1192 & 557.3 & 41.392 \\
\hline 1998 & 0.108 & 1238 & 524 & 40.313 \\
\hline 1999 & 0.135 & 1359 & 512 & 65.1 \\
\hline 2000 & 0.339 & 1386 & 507 & 103.5 \\
\hline 2001 & 0.323 & 1616 & 495 & 124.9 \\
\hline 2002 & 0.129 & 1546 & 532 & 146.3 \\
\hline 2003 & 0.207 & 1684 & 496 & 191.2 \\
\hline
\end{tabular}

Table 2. Evaluation of the quality of the regression model.

\begin{tabular}{|l|c|c|}
\hline Factors (independent variables) & & Dependent variable \\
\hline Free member & & $0.0486-3.2188523606$ \\
\hline Vinv & 1 & 0.1097 \\
& $\mathrm{t}$ & 2.2519463545 \\
\hline Vatm $^{(\mathrm{P})}$ & 1 & 0.0508 \\
& $\mathrm{t}$ & 3.1608124173 \\
\hline Vwater $^{(\mathrm{P})}$ & 1 & 0.0423 \\
& $\mathrm{t}$ & 3.4054700044 \\
\hline F - statistics & & 62.50849 \\
\hline The level of significance for F & & 0.0033 \\
\hline R - square & & 0.98254 \\
\hline
\end{tabular}

The data in Table 2 show that all t-statistics are larger than or close to 3 in absolute value. A very high proportion of the variance of the dependent variable, explained with the help of the regression equation, is above $98 \%$. Based on the values of F-statistics, the hypothesis of the simultaneous zeroing of all the co-efficients of regression is certainly rejected. Thus, the statistical quality of the regression equation obtained is considered to be quite high.

Based on the current technical and technological state of industries, an approximate level of investment, ensuring a minimum coverage of environmental pollution can be estimated at 2 billion rubles. When recalculating in prices in 2016, taking into account inflation, this amount can be estimated at 7 billion rubles.

The current level of costs for environmental protection in the region, roughly corresponds to the minimum value (Table 3 ).

Table 3. The amount of the regional budget for environmental purposes [4].

\begin{tabular}{|c|c|c|}
\hline Year & $\begin{array}{c}\text { The total amount of funds aimed at protecting } \\
\text { and restoring the environment, million rubles. }\end{array}$ & $\begin{array}{c}\text { Funds of enter- } \\
\text { prises, \% }\end{array}$ \\
\hline 2012 & 5708 & 26.3 \\
\hline 2013 & 7579 & 29 \\
\hline 2014 & 10224 & 14 \\
\hline 2015 & 6858 & 22 \\
\hline 2016 & 7250 & 19 \\
\hline
\end{tabular}

Most of the costs are borne by the budget, while the main persons causing destructive impact are direct users of nature - industrial enterprises. Responsibility is distributed extremely unevenly, business profits, and negative consequences are entirely borne by the regional authorities and the population. At the same time, in line with the main forecast 
indicators for the period up to 2020, the share of environmental protection spending as a percentage of GDP(gross domestic product) will increase, but the share of these expenditures will remain low, to $0.2-0.3 \%$ of GDP in 2025 . In general, the level of environmental costs (costs for reducing harmful emissions, recycling and restoring the natural environment) could increase to $1-1.5 \%$ of GDP by 2020 , while experts believe that to stabilize the quality of the natural environment in general, at the level of the national economy, it is necessary that the level of environmental costs is $6 \%$ of GDP $[5,6]$, and to significantly improve its state, $8-10 \%$ of GDP is needed. In the conditions of the financial crisis, it is not necessary to hope for an increase in environmental costs [5].

The total amount of funds allocated for the protection of the environment for the period 2012-2016. in general, covers the needs of the region in environmental investments, according to the model given. However, enterprise funds do not exceed $30 \%$ of the required amount, which indicates a low level of social responsibility of enterprises-nature users of the region.

\section{Results and discussion}

In order to analyze the real level of social responsibility of business entities of Kemerovo region, we conducted its evaluation, using the system of indicators proposed by A.A Watlin [7]. However, the system proposed by him is aimed mainly at assessing corporate social responsibility. The social responsibility of business is a more global concept, including the responsibility of corporations to their employees, as one of the components [8-10].

We propose to complement the set of indicators, indicators that allow us to assess the level of social responsibility of business. In augmented form, the system of evaluation indicators, allowing to assess the level of social responsibility of a business entity, will look like this.

Institutional indicators (I):

The application of standards and standards of social responsibility in the current activities of the enterprise (I 1)

The availability of the document defining the social policy of the enterprise (I 2)

Orientation of internal business processes to social focus (I 3)

Providing comfortable working conditions (I 4)

Providing the improvement of the territory of presence (I 5)

The level of investment to the environmental protection (I 6)

Social support and protection of needy population groups (I 7)

Strategic indicators (S):

The using of methods to improve the organization of production (S1)

System for assessing the effectiveness of social investment (S2)

The presence of external socially-oriented communications (S3)

The nature of public-private partnership (at the regional level) (S4)

The purpose of using social policy instruments (S5)

Implementation of environmental policy in the territory of the presence (S6)

Economic indicators (E)

Energy efficiency growth rate (E1)

Rate of increasing in labor productivity (E2)

Net profit of the enterprise and tax deductions (E3)

The availability and volume of social spending (E4)

Policy of resource saving and nature protection activity (E5)

The ratio of the enterprise's profit to the volume of social investment (E6)

Organizational indicators $(O)$

A special unit implementing social programs 
The level of safety at the enterprise $\left(\mathrm{O}_{2}\right)$

Sponsorship, philanthropy $\left(\mathrm{O}_{3}\right.$

Systematic non-financial reporting of the enterprise $\left(\mathrm{O}_{4}\right)$

Interaction with the local population $\left(\mathrm{O}_{5}\right)$

Interaction with the management of the territory of presence $\left(\mathrm{O}_{6}\right)$

Each indicator changes from 0 to 1.0 .

The sample of the study is presented by large industrial enterprises of Kemerovo region, as they are focused on social responsibility.

The analysis was carried out on the enterprises of the industrial sector: coal, metallurgy, chemical industry, construction (Table 4).

Table 4. The actual integral indicator and the qualitative index of social investments of mining enterprises of Kemerovo region.

\begin{tabular}{|c|c|c|c|}
\hline Company & Kind of activity & $\begin{array}{l}\text { Actual integral } \\
\text { indicator. Ifact }\end{array}$ & $\begin{array}{c}\text { Quality index of } \\
\text { social invest- } \\
\text { ments, IK, \% }\end{array}$ \\
\hline $\begin{array}{l}\text { Open Join-Stock Company } \\
\text { (OJSC) "Yuzhkuzbassugol" }\end{array}$ & $\begin{array}{l}\text { Extraction and processing } \\
\text { of coal }\end{array}$ & 12.25 & 48 \\
\hline OJSC "Kuzbassrazrezugol” & $\begin{array}{l}\text { Extraction and processing } \\
\text { of coal }\end{array}$ & 8 & 28 \\
\hline $\begin{array}{l}\text { Closed Join-Stock Compa- } \\
\text { ny (CJSC) "Stroyservice"" }\end{array}$ & $\begin{array}{l}\text { Extraction and processing } \\
\text { of coal }\end{array}$ & 11.75 & 46.5 \\
\hline $\begin{array}{l}\text { Siberian Business Union. } \\
\text { SDS-coal }\end{array}$ & $\begin{array}{l}\text { Extraction and processing } \\
\text { of coal }\end{array}$ & 13 & 52.6 \\
\hline CJSC "Mine Raspadskaya" & $\begin{array}{l}\text { Extraction and processing } \\
\text { of coal }\end{array}$ & 6.75 & 26 \\
\hline Southern Kuzbass & $\begin{array}{l}\text { Extraction and processing } \\
\text { of coal }\end{array}$ & 5 & 20 \\
\hline SDS-coal & $\begin{array}{l}\text { Extraction and processing } \\
\text { of coal }\end{array}$ & 5.5 & 21 \\
\hline Kuzbass Fuel Company & $\begin{array}{l}\text { Extraction and processing } \\
\text { of coal }\end{array}$ & 5.5 & 21 \\
\hline Belon & $\begin{array}{l}\text { Extraction and processing } \\
\text { of coal }\end{array}$ & 9 & 34 \\
\hline Chernigovets & $\begin{array}{l}\text { Extraction and processing } \\
\text { of coal }\end{array}$ & 10.75 & 43 \\
\hline Mezhdurechie & $\begin{array}{l}\text { Extraction and processing } \\
\text { of coal }\end{array}$ & 14.75 & 54.7 \\
\hline $\begin{array}{l}\text { Novokuznetsk aluminum } \\
\text { plant }\end{array}$ & Non-ferrous metallurgy & 9.5 & 34.52 \\
\hline $\begin{array}{l}\text { West-Siberian } \\
\text { Metallurgical Combine }\end{array}$ & Ferrous metallurgy & 8 & 30.7 \\
\hline Kuznetsk ferroalloys & Ferrous metallurgy & 8 & 30.7 \\
\hline $\begin{array}{l}\text { Guryevsk Metallurgical } \\
\text { Plant }\end{array}$ & Ferrous metallurgy & 6.75 & 26 \\
\hline OJSC "KOKS" & Ferrous metallurgy & 12.25 & 48 \\
\hline SGMK-Trade & Ferrous metallurgy & 8.25 & 31.7 \\
\hline Evrazruda & Ferrous metallurgy & 15.25 & 56.55 \\
\hline $\begin{array}{l}\text { Yurginsky Machine- } \\
\text { Building Plant }\end{array}$ & Mechanical engineering & 17.25 & 66.3 \\
\hline AZOT & $\begin{array}{l}\text { Production of mineral } \\
\text { fertilizers, synthetic am- } \\
\text { monia, caprolactam }\end{array}$ & 17.5 & 67 \\
\hline
\end{tabular}


As a result enterprises are grouped according to the level of social responsibility, the assignment of the enterprise to different groups occurred on the basis of two indicators:

1. Actual integral indicator of social responsibility. It demonstrates the degree of inclusion of the whole set of criteria in daily activities and allows you to estimate the variance from the ideal value of the integral indicator.

2. The qualitative index of social investments demonstrates the level of complexity of the social activity of the enterprise.

Depending on the size of the indicator, several groups of enterprises with different degrees of activity of social responsibility can be distinguished: companies with a social investment index from 16 to $30 \%$, from 30 to $50 \%$, from 50 to $80 \%$ and above $80 \%$.

The results of the calculations show that only $5 \%$ of companies operating on its territory can be attributed to enterprises with the highest level of social responsibility in the region, to the group of enterprises with an average level of social responsibility - $15 \%$, below the average $-40 \%$, and $40 \%$ of the largest business entities, in fact, do not pay attention to social responsibility in front of the territory of presence.

\section{Conclusion}

In our opinion, it is necessary to determine in absolute values in each particular region the necessary amount of investment in the elimination of environmental consequences. It is also necessary to determine the share of pollution of each enterprise in the total population. Based on the specific amount of investment needed to restore the environment, build relationships with the owners of polluting enterprises.

\section{References}

1. Volume of investments in fixed assets. Central Statistical Data Base (Rosstat, Moscow, 2017)

2. N. N. Golofastova, V. G. Mikhailov, I. V. Seredyuk Economics and Innovation Management, 1, 66-75 (2017) DOI: 10.26730/2587-5574-2017-1-66-75

3. I. S. Trapeznikova, Ecological factor in the development of the economy of the raw material region (based on the example of Kemerovo region) (KemSU, Kemerovo, 2005)

4. Federal Service of State Statistics. Territorial organ of the Federal Service (Rosstat, Moscow, 2017)

5. A. V. Myaskov, S. M Popov, Economics and Innovation Management, 1, 16-24 (2018) DOI: $10.26730 / 2587-5574-2018-1-16-24$

6. V. E. Telentinov, Economics of nature management, 2, 8-19 (1999)

7. A. A. Vatlin, Management of corporate social responsibility as a factor of sustainable development of the organization (TSU, Tambov, 2015)

8. F. Agafonov, A. Genin, O. Kalinina, O. Brel, O. Zhironkina, E3S Web of Conf., 15, 04011 (2017)

9. E. Shavina, O. Kalenov, E3S Web of Conferences 21, 04025 (2017)

10. A.A. Khoreshok, S.A. Zhironkin, M.A. Tyulenev, G.A. Barysheva, V.Y. Blumenstein, M.C. Hellmer, S.V. Potyagailov, IOP Conf. Ser.: Mater. Sci. Eng., 142: 1, 012122 (2016) 